Bangladesh J. Plant Taxon. 26(2): 315-324, 2019 (December)

(C) 2019 Bangladesh Association of Plant Taxonomists

\title{
SEED MICROMORPHOLOGICAL STUDY ON ENDEMIC AND SUBENDEMIC SPECIES OF VERONICA L. (PLANTAGINACEAE JUSS.) IN IRAN
}

\author{
Soghra Ramzi ${ }^{1}$ and Shahryar SAedi-Mehrvarz \\ Department of Biology, Faculty of Science, University of Guilan, Rasht, Iran \\ Key words: Micromorphology; Endemic; Seed; Veronica; Iran.
}

\begin{abstract}
Seed morphology of 12 Iranian endemic and subendemic species of Veronica was studied using scanning electron microscope (SEM). Seven qualitative and quantitative characters were measured using SEM micrographs and stereomicroscopy. The seed shape of most species is ovate and plano-convex. The size of seeds ranges from $1.25 \times$ $0.75 \mathrm{~mm}$ in $V$. khorassanica to $2.5 \times 1.75 \mathrm{~mm}$ in $V$. viscosa Boiss. The ornamentation of seed coat is reticulate-verrucate in $V$. khorassanica, $V$. czerniakowskiana, $V$. mazanderanae and $V$. rubrifolia, reticulate-rugate in $V$. acrotheca, $V$. aucheri, $V$. viscosa and $V$. intercedens, rugose in $V$. microcarpa, $V$. chionantha and $V$. rechingeri, and reticulate-porate in $V$. gaubae. The testa cells are polygonal in ten species and irregular in two species. Micromorphological characters of seeds are useful in specific and subspecific delimitations of Iranian Veronica.
\end{abstract}

\section{Introduction}

Veronica L. (Plantaginaceae sensu APG, 2003; formerly Scrophulariaceae) is the largest genus within tribe Veroniceae Bartling. with ca. 450 species (Albach et al., 2004a). Endemic species are important on both global and local levels, as they provide unique genetic diversity for further studies and provide local people with priceless services (Newmark, 2002). Fischer (1981) introduced the genus Veronica in Flora Iranica with 56 species and arranged these species in five sections. According to the flora of Iran the genus includes 61 species with 18 endemics among them (Saeidi-Mehrvarz, 2003). Alborz and Zagros mountains of Iran are an important center of speciation of Veronica. Many endemic species of this genus occur in Alborz range, such as $V$. siaretensis E. Lehm., V. rechingeri M.A. Fisch., V. mazanderanae Wendelbo and V. chionantha Bornm. In foothills of Kopet-Dagh in northeastern Iran, some species such as V. khorassanica Czerniak. and V. czerniakowskiana Monjuschko are endemic (Saeidi-Mehrvarz, 2005). The distribution range of $V$. acrotheca Bornm. \& Gauba and $V$. rubrifolia Boiss. is in western Iran, whereas $V$. rechingeri and $V$. gaubae Bornm. occur in northern Iran. These endemics of Veronica and most of the ones restricted to Iran and adjacent regions belong to two subgenera, Pocilla (Dumort.) M. Mart. Ort., Albach \& M.A. Fisch. and Pentacepala (L. B. Moore) Garn.-Jones.

Macro- and micromorphological characters of seed are of essential systematic importance within Veronica (Yamazaki, 1957; Juan et al., 1994; Martínez-Ortega and Rico, 2001; MunozCentento, 2006). Several authors such as Elisens and Tomb (1983) and Barthlott (1984) have emphasized the phylogenetic and systematic value of the structural character of the seed coat, due to their low phenetic variation. The shape of seed has been traditionally used in Veronica as an important taxonomic character (Martínez-Ortega and Rico, 2001). Güld (2013) studied seed morphology of six Turkish species of Veronica viz. V. bozakmanii M. A. Fisch, V. arvensis L.,

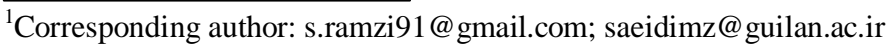


$V$. triphyllos L., V. polita Fr., V. hederifolia L. and V. cymbalaria Bodard by SEM. MartínezOrtega and Rico (2001) studied seed morphology and its systematic significance in some Veronica species (Scrophulariaceae), mostly from the Western Mediterranean. Some studies have been carried out on Iranian species, seed and fruit micromorphological study (Saeidi-Mehrvarz et al., 2001a,b). The seed morphology of ten Iranian Veronica species have been reported by SaeidiMehrvarz et al. (2001b). İt was the first step of seed micromorphological study on Veronica of Iran. The present study aims to record the seed micromorphological characters of 12 Iranian endemic and subendemic species of genus Veronica and evaluate their taxonomic significance for the first time.

\section{Materials and Methods}

This study was mainly based on the specimens deposited in Tehran University Herbarium (TUH) and Guilan University Herbarium (GUH). Approximately 10 seeds from each taxon were analyzed. Macromorphological observations were carried out under a Stereoscopic Microscope (SM). For SEM, seeds were directly mounted on metallic stubs using double-sided adhesive tape and then coated with gold for $6 \mathrm{~min}$ in a sputtering chamber before observed under SEM. The SEM examination was carried out under a VEGA/TESCAN SEM, at an accelerating voltage of 15 $\mathrm{kV}$, in Razi Metallurgical Research Center (RMRC) in Tehran. The terminology used to describe seed coat surface sculpturing follows mainly Juan et al. (1994), Martinez-Ortega and Rico (2001) and Mounzu-Centento et al. (2006). Circumscription of subgenus follows the system by Albach et al. (2004a).

\section{Results and Discussion}

The seed size in the studied Iranian Veronica ranges from 1 to $3 \mathrm{~mm}$ in length and 0.5 to 2 $\mathrm{mm}$ in width. Seeds of Veronica species are ovate, cymbiform, flattened, plano-convex or cyathiform in shape (Table 1). Color of seeds are dark brown to yellow. The cells are mostly polygonal in studied taxa with exception of $V$. chionantha and $V$. rechingeri, where they are irregular. There is some variation in depth, thickness and ornamentation of anticlinal and periclinal walls. Periclinal wall mostly was flattened and it may have had ornamentation that forms a secondary sculpture. Sculpturing pattern showed four different type: reticulate-verrucate, reticulate-rugose, rugate and reticulate-porate. Among the species examined, only V. gaubae showed type of reticulate-porate. The seed morphological characters of the studied taxa are shown in Table 1 and Figs 1-4. A taxonomic key to the species and subspecies of Iranian Veronica based on seed characters has been generated for their identification.

\section{A taxonomic key to the species and subspecies of Veronica of Iran.}

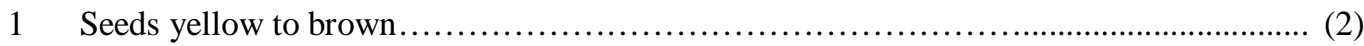

Seeds dark brown

2 Seeds cymbiform

Seeds ovate, flattened.

3 Seed coat rugate, anticlinal wall with medium depth, periclinal wall concave and smooth, terminal funicular attachment. V. microcarpa

- Seed coat reticulate-rugate, anticlinal wall obscure, periclinal wall convex and corrugate, subterminal funicular attachment............................................

4 Seed coat surface reticulate-verrucate. 
Seed coat surface not reticulate-verrucate

5 Seeds plano-convex, brown.

- Seeds cyathiform or subcyathiform, yellow to brown.

6 Thick anticlinal wall with medium depth, flat periclinal wall with a large conspicuous central wart. V. khorassanica

- Thin and shallow anticlinal wall, flat periclinal wall with a central wart not very conspicuous. V. czerniakowskiana

7 Brown, cyathiform, smooth in dorsal face, thin anticlinal wall, funicular attachment V. mazanderanae

- Yellow to brownish, cyathiform or subcyathiform, cristate, thick anticlinal wall, papillate or micro reticulate.

8 Cyathiform, yellow, with deep ridge on dorsal face. V. rubrifolia subsp. rubrifolia Subcyathiform, brownish, ridge on dorsal face is not deep. V. rubrifolia subsp. respectatissima

9 Seed coat rugate, irregular cells, indistinct cell boundaries, subterminal funicular attachment ............................................................. rechinger

- Seed coat reticulate, polygonal cell, anticlinal wall with medium depth, terminal funicular attachment.

10 Flattened to cyathiform, yellow, seed coat reticulate-rugate, periclinal wall without any pore

Plano-convex, brown, seed coat reticulate-porate, periclinal wall with a central pore.

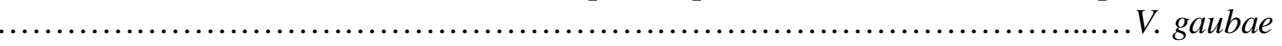

11 Flattened, with a keel at dorsal face. V. viscosa

- Cyathiform, dorsal face rough and without a keel V. intercedens

12 Seed coat rugate, irregular cells, ring structures in dorsal face................ V. chionantha

- Seed coat reticulate-rugate, polygonal cells, without any special structures in dorsal face. V. acrotheca

Some authors have determined the genus circumscription of Veronica using seed characters (Yamazaki, 1957; Juan et al., 1994; Mortinez-Ortega and Rico, 2001; Munoz-Centeno et al., 2006). In all cases these characters were useful at infrageneric rank. Seed coat in most species was reported as reticulate-verrucate. This pattern was found as common in Veronica and in most species of subg. Pentasepala (Munoz-Centeno et al., 2006). In our study it appears in subg. Pentasepala twice, in V. khorassanica and V. czerniakowskiana. It seems that seed coat in the ancestor of subg. Pellidosperma (E.B.J. Lehm.) Assejeva, Stenocarpon (Boriss.) M.M. Mart. Ort., Albach \& M.A. Fisch., Chamaedrys (W.D.J. Koch) M. Mart., Pocilla and Pentasepala was reticulate-verrucate (Munoz-Centeno et al., 2006). According to Albach et al. (2004b) V. czerniakowskiana is a sister clad to a group of Veronica species, such as $V$. jacquinii, $V$. turrillanaand $V$. bombycine. These species also show reticulate-verrucate pattern (Munoz-Centeno et al., 2006). Among the species of subg. Pentasepala, perennials exhibit reticulate-verrucate in $V$. aucheri Boiss. and $V$. acrotheca, and rugate in $V$. chionantha and $V$. rechingeri. These patterns have been mentioned as rare cases in earlier studies (Mortinez-ortego and Rico 2001, MunozCenteno et al., 2006). V. acrotheca and V. aucheri, despite similar seed coat and shape, are separable in some characters, such as thickness of anticlinal cell wall. 

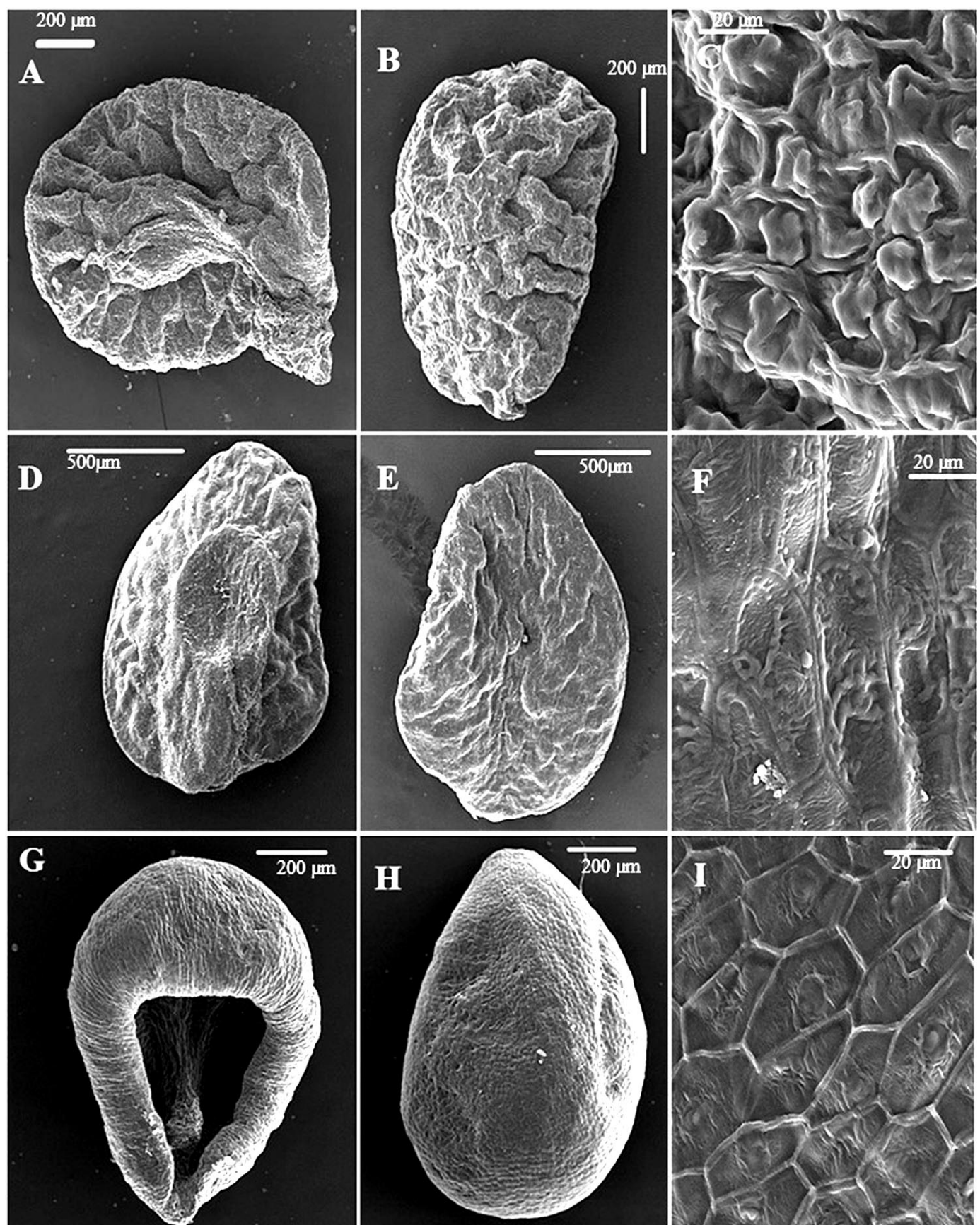

Fig. 1. SEM Micrographs of Veronica seeds. A, D, G Ventral face, B, E, H Dorsal face, C, F, I seed coat. AC: V. khorassanica, D-F: V. czerniakowskiana, G-I: V. mazandranae. 

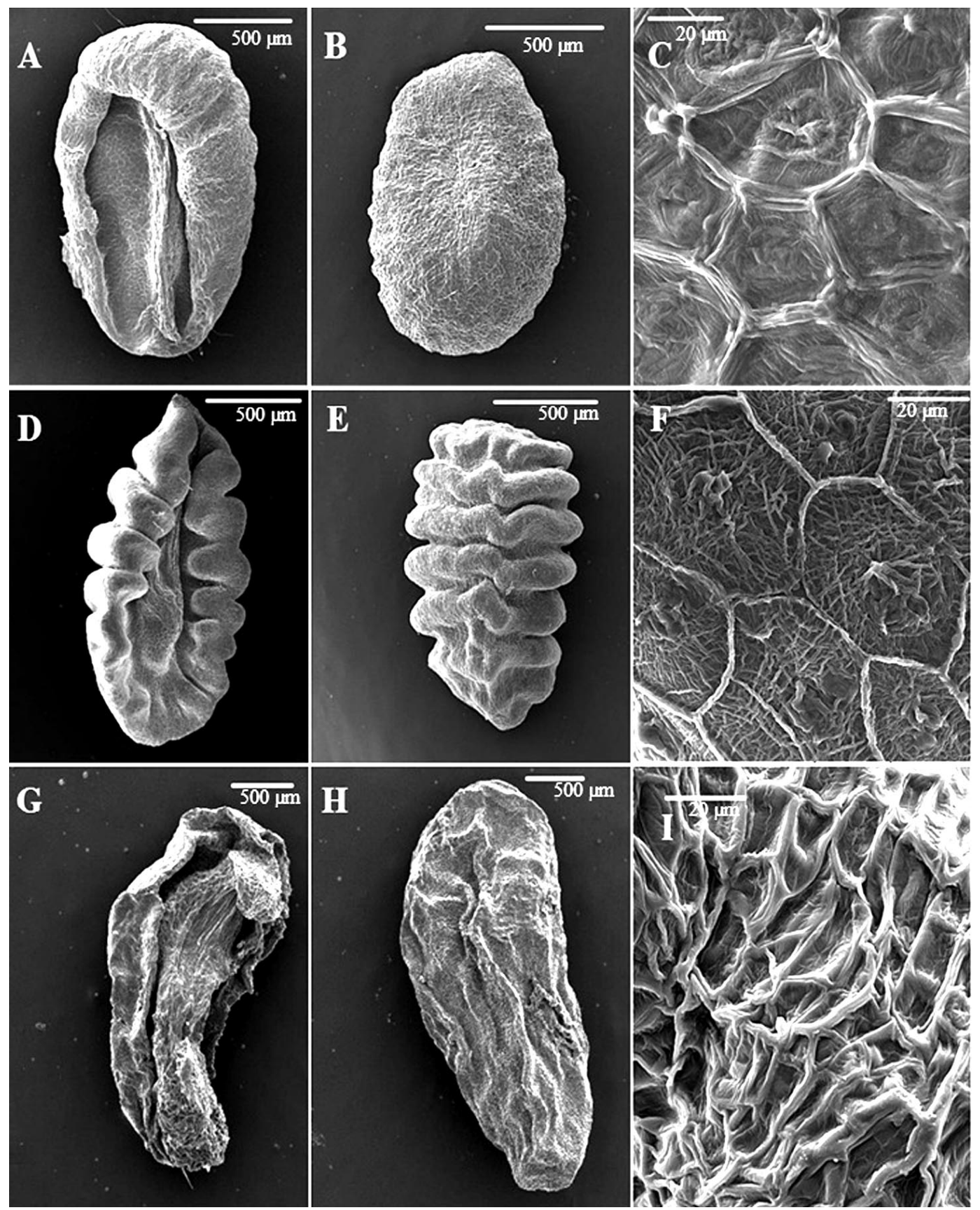

Fig. 2. SEM Micrographs of Veronica seeds. A, D, G Ventral face, B, E, H Dorsal face, C, F, I, seed coat. AC: V. rubrifolia subsp. respectatissima, D-F: V. rubrifolia subsp. rubrifolia, G-I: V. acrotheca. 

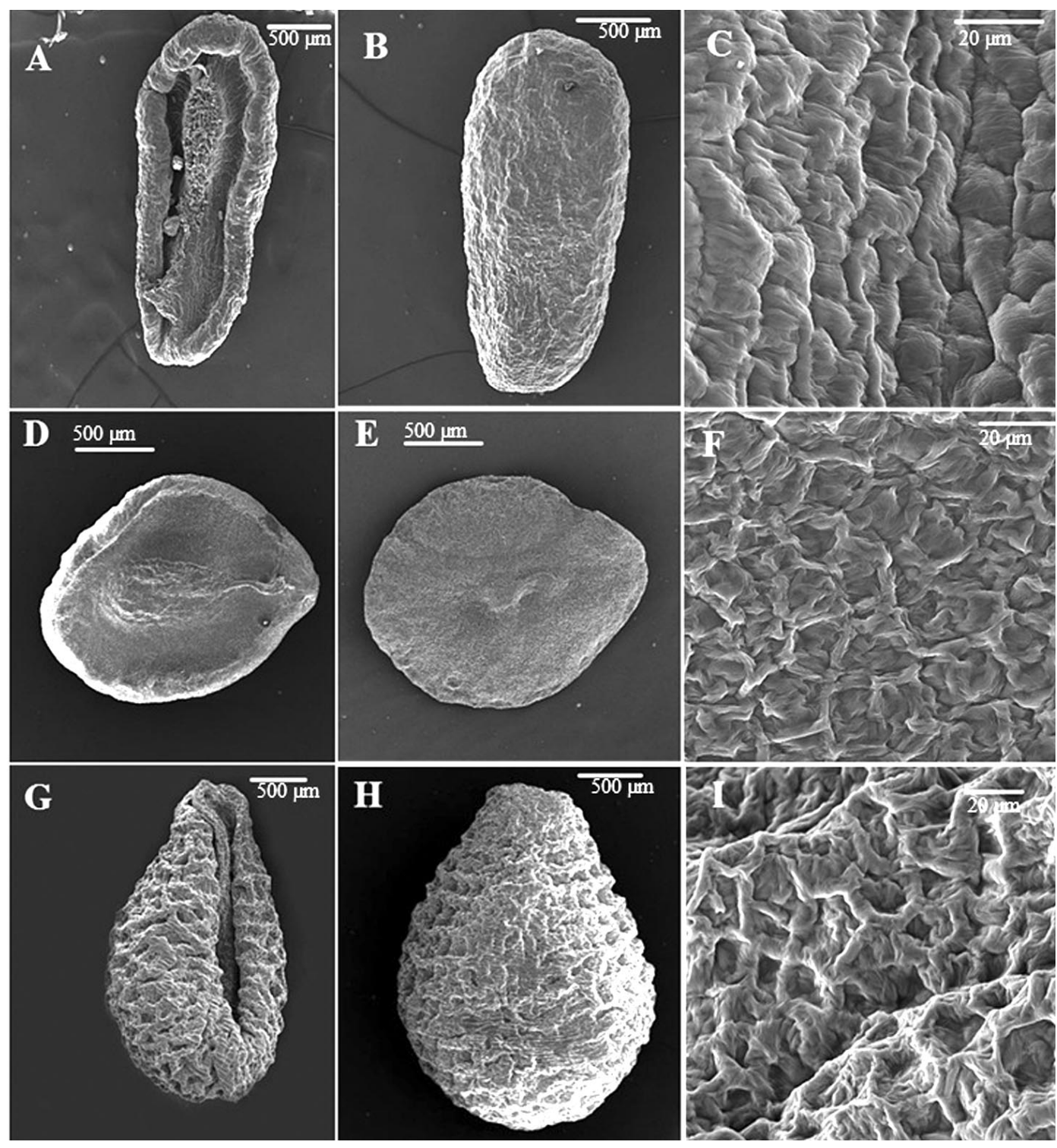

Fig. 3. SEM Micrographs of Veronica seeds. A, D, G Ventral face, B, E, H Dorsal face, C, F, I, seed coat. A-

C: V. aucheri, D-F: V. viscosa, G-I: V. intersedens.

Dorsal face of seed coat in $V$. chionantha has a particular structure that is introduced here for the first time. Four to five raised rings with a central cavity that form a pillar. Among the species from subg. Pentasepala only $V$. rechingeri shows flattened seeds. $V$. gaubae of subg. Pentasepala exhibit a particular pattern in seed coat. It is reticulate-porat because of a periclinal wall with a central pore. This pattern has not been reported so far. V. viscosa and V. intercedens Bornm. from subg. Pocilla show reticulate-rugate. Earlier this pattern was reported in V. stylophora Popov and 

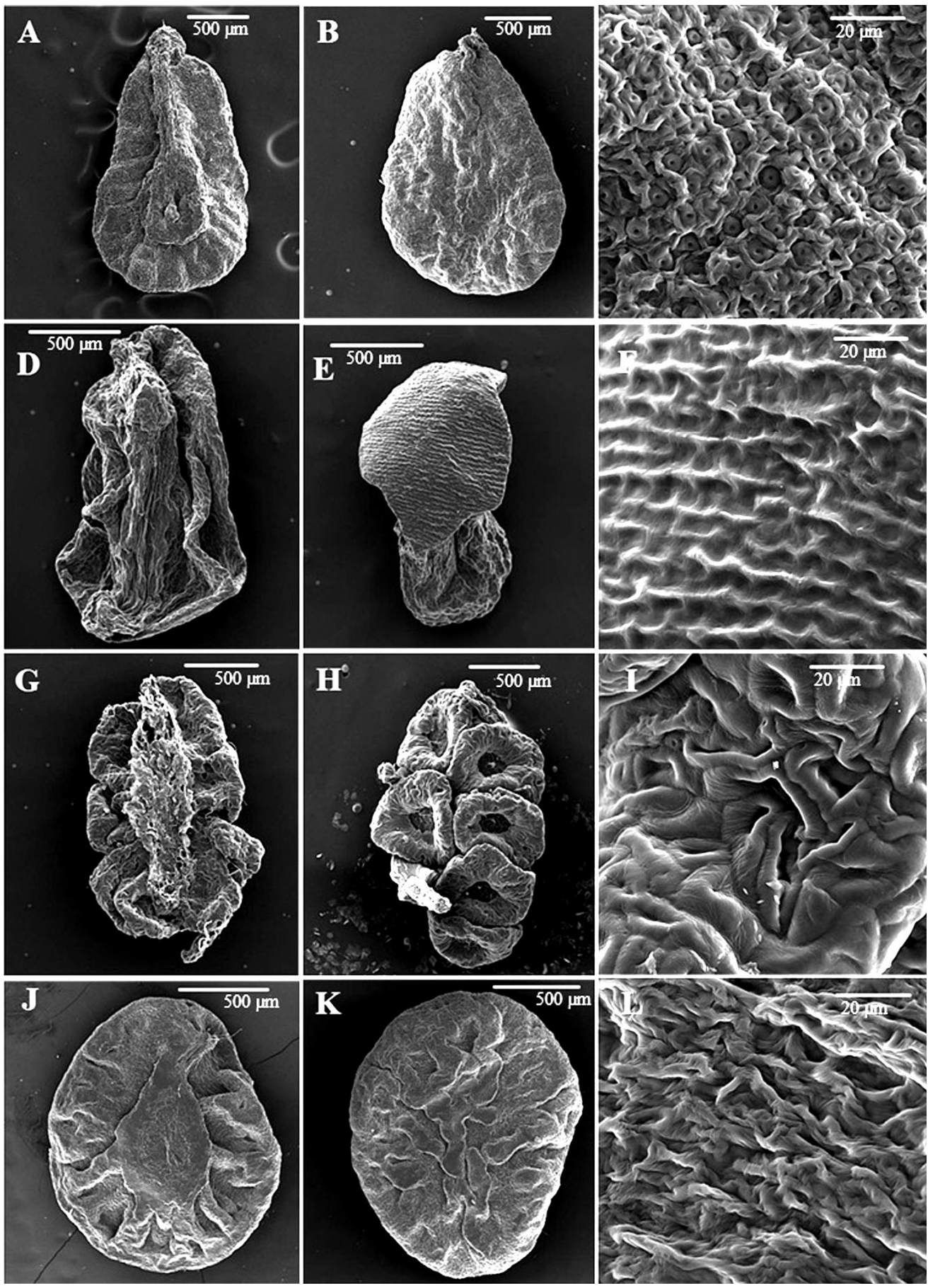

Fig. 4. SEM Micrographs of Veronica seeds. A, D, G, J Ventral face, B, E, H, K Dorsal face, C, F, I, L seed coat. A-C: V. gaubae, D-F: V. microcarpa Boiss., G-I: V. chionantha, J-L: V. rechingeri. 


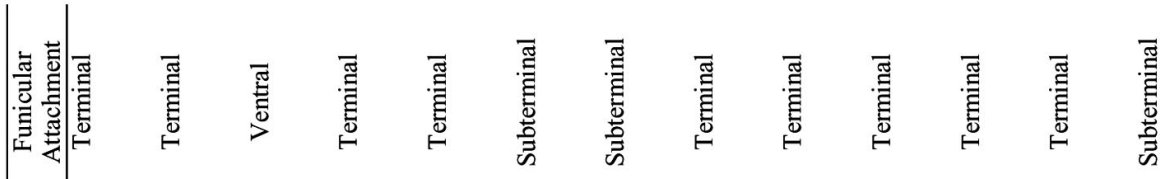

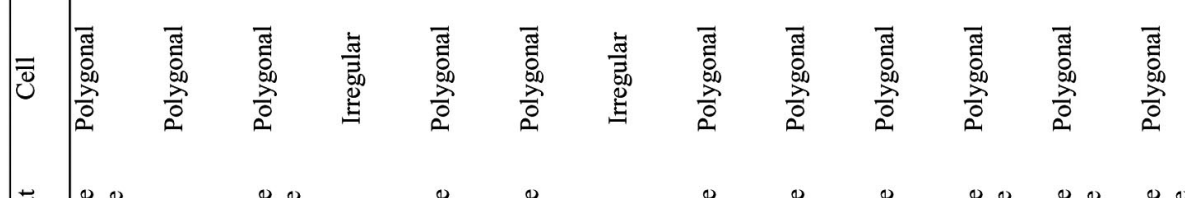

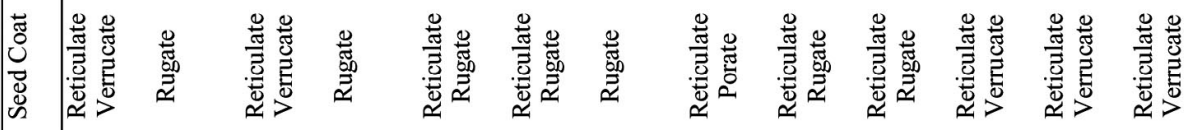

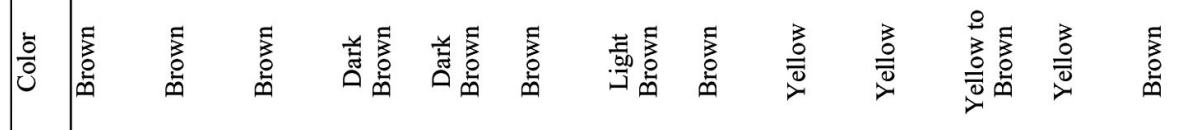

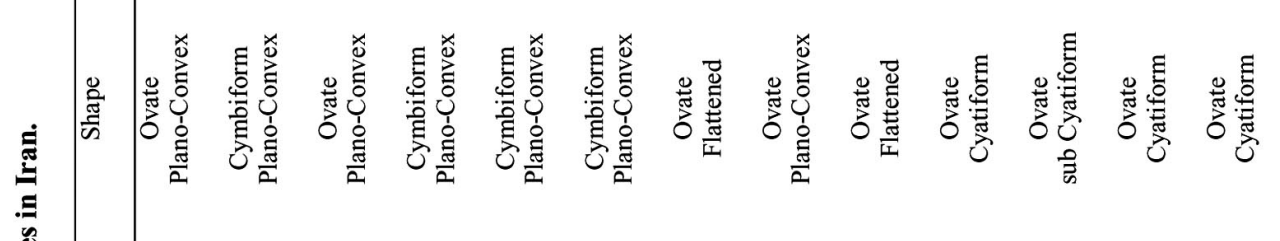

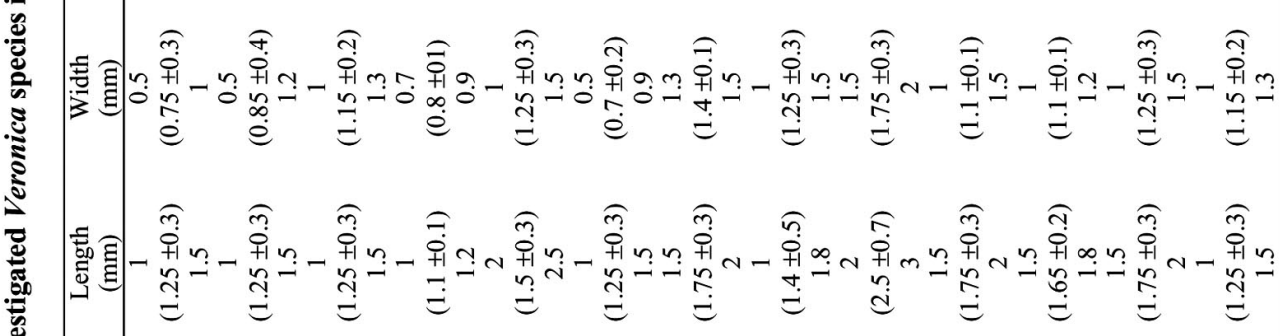

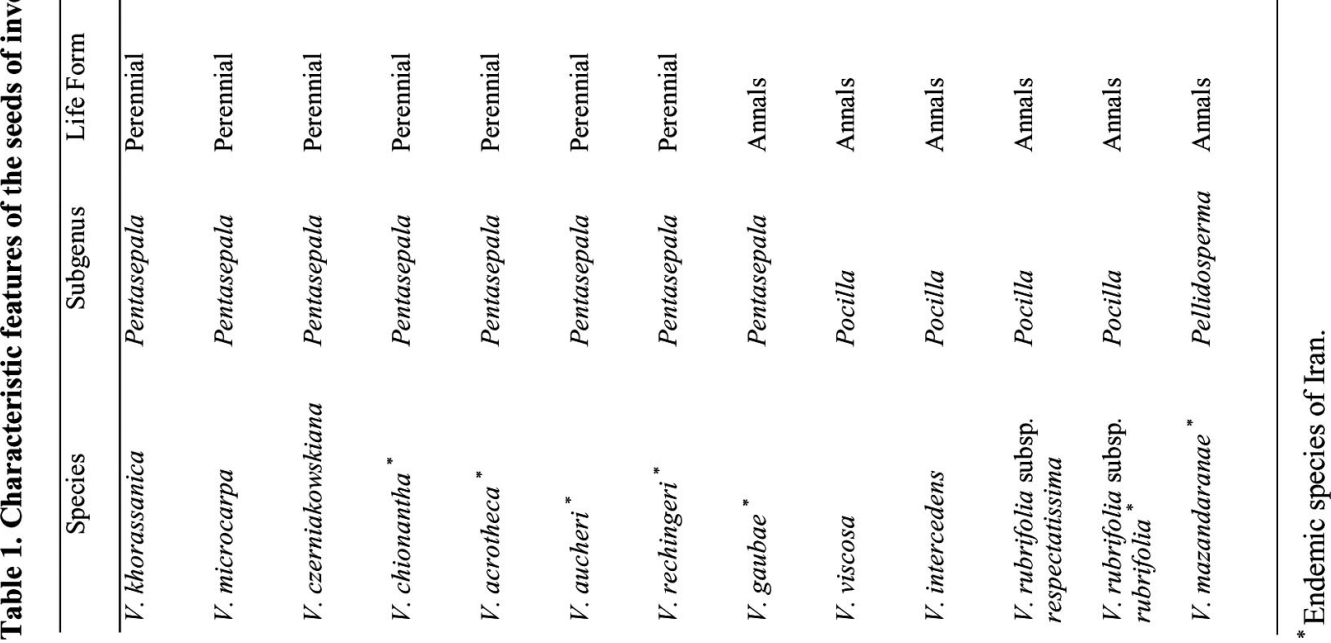


$V$. capillipes Nevski of this subgenus (Munoz-Centeno et al., 2006). V. intercedens is similar to $V$. capillipes with a cyathiform seed shape, unlike $V$. viscosa where it is flattened. The seed shape and seed coat of $V$. rubrifolia are reported to be cyathiform and cristate at dorsal face (Munoz-Centeno et al., 2006; Hassan and Khalik, 2014). In this study, seed shape of V. rubrifolia subsp. respectatissima M.A. Fischer is found as sub-cyathiform, though it is cyathiform in V. rubrifolia subsp. rubrifolia Boiss. Two subspecies of $V$. rubrifolia differ in ornamentation of periclinal wall. It is papillate in $V$. rubrifolia subsp. rubrifolia and microreticulate in $V$. rubrifolia subsp. respectatissima. The finding of reticulate-verrucate seed coat in V. rubrifolia in this study is supported by Munoz-Centeno et al. (2006) and Albach et al. (2008). In V. mazandranae, the only representative of subg. Pellidosperma, seeds are sub-cyathiform and smooth in dorsal face. This is accordant with the result of Munoz-Centeno et al. (2006) who show that the seeds in this subgenus are sub-cyathiform or cymbiform. The finding of seed coat in V. mazandranae as reticulateverrucate is concordant with the observation of Munoz-Centeno et al. (2006) in subg. Pellidosperma. This study indicates that seed characters, such as shape, size, dorsal surface, testa cells, and surface ornamentation etc. are useful in identification and classification of the Veronica species studied. Micromorphological characters of seeds seem reliable for taxonomic delimitation at both specific and subspecific levels in Iranian Veronica. Further studies on seed morphology of Veronica species based on broader species sampling are needed for more comprehensive conclusion.

\section{Acknowledgements}

This research was supported by a research fund from Guilan University.

\section{References}

Albach, D.C., Martínez-Ortega, M.M., Delgado, L., Weiss-Schneeweiss, H., Özgökce, F., and Fischer, M. A. 2008. Chromosome Numbers in Veroniceae (Plantaginaceae): Review and Several New Counts1. Ann Mo Bot Gard 95: 543-566.

Albach, D.C., Martínez-Ortega, M.M., Fischer, M.A., and Chase, M.W. 2004a. Evolution of Veroniceae: a phylogenetic perspective. Ann Mo Bot Gard 91: 275-302.

Albach, D.C., Martínez-Ortega, M. M., Fischer, M.A., and Chase, M.W. 2004b. A new classification of the tribe Veroniceae-problems and a possible solution. Taxon 53: 429-452.

Barthlott, W. 1984. Microstructural Features of Seed Surfaces. In: Heywood, V.H. and Moore, DM. (Eds.), Current Concepts in Plant Taxonomy. Academic Press, London, pp. 95-105.

Elisens, W.J., and Tomb, S.A. 1983. Seed morphology in New World Antirrhineae (Scrophulariaceae): Systematic and phylogenetic implications. Plant Syst. Evol. 14: 23-47.

Fischer, M.A. 1981. Veronica L. In: Rechinger K.H. (Ed.), Flora Iranica, Vol. 147. Akademie der Wissenschaften, Graz, Austria, pp. 25-165.

Güld, Y. 2013. Seed Morphology Studies on some Veronica L. Species (Plantaginaceae) with Scanning Electron Microscopy. Rom Biotechnol Lett 18: 8180-889.

Hassan, N.M., and Khalik, K. N.A. 2014. Systematic significance of seed morphology in the genus Veronica (Plantaginaceae), with special reference to the Egyptian taxa. J. Syst. Evol. 52: 215-230.

Juan, R., Pastor, J., and Fernandez, I. 1994. Seed morphology in Veronica L. (Scrophulariaceae) from south-west Spain. Bot. J. Linn. Soc. 115: 133-143.

Martínez-Ortega, M.M., and Rico, E. 2001. Seed morphology and its systematic significance in some Veronica species (Scrophulariaceae) mainly from the Western Mediterranean. Plant Syst. Evol. 228: 15-32. 
Munoz-Centeno, L.M., Albach, D.C., Sánchez-Agudo, J. A., and Martinez-Ortega, M. M. 2006. Systematic significance of seed morphology in Veronica (Plantaginaceae): a phylogenetic perspective. Ann. Bot. London 98: 335-350.

Newmark, W.D. 2002. Conserving biodiversity in East African forests: a study of the Eastern Arc Mountains. Springer Science \& Business Media 155: 1-205

Saeidi-Mehrvarz, S., Ghahreman, A., and Assadi, M. 2001a. Fruit structure of some species Veronica (Scrophulariaceae: Veroniceae) from Iran. Iran. Journ. Bot. 9: 111-121.

Saeidi-Mehrvarz, S., Ghahreman, A., and Assadi, M. 2001b. Notes on the genus Veronica (Scrophulariaceae: Tribe Veroniceae) in Iran: Seed characters and a new record. Pak. J. Bot. 33: 143-152.

Saeidi-Mehrvarz, S. 2003. Veronica longipedicellata (Scrophulariaceae), a new species from Iran. Nord. J. Bot. 23: 559-561.

Saeidi-Mehrvarz, S. 2005. Distribution pattern of the genus Veronica L. in Iran. Bangladesh J. Bot. 34: 7175.

Saeidi-Mehrvarz, S. and Kharabian, A. 2005. Chromosome counts of some Veronica L. (Scrophulariaceae) species from Iran. Turk. J. Bot. 29: 263-267.

Yamazaki, T. 1957. Taxonomical and phylogenetic studies of Scrophulariaceae-Veroniceae with special reference to Veronica and Veronicastrum in Eastern Asia. J. Fac. Sci. U Tokyo 37: 92-162.

(Manuscript received on 4 July 2019, revised on 9 December 2019) 